\title{
Assessment of pharmaceutical services in HIV/AIDS health units in the city of Niterói, Brazil
}

\author{
Nilo Jorge Piccoli ${ }^{1}$, Monique Araújo de Brito ${ }^{1,2}$, Selma Rodrigues de Castilho ${ }^{1,2, *}$
}

${ }^{1}$ Pharmaceutical Assistance Management Master Course, Fluminense Federal University, Niterói, RJ, Brazil, ${ }^{2}$ Department of Pharmacy and Pharmaceutical Management, Federal Fluminense University, Niterói, RJ, Brazil

\begin{abstract}
This study aimed to conduct an assessment of pharmaceutical services in HIV/AIDS in the city of Niteroi, Brazil, with emphasis on management. It was done a descriptive cross-sectional study, and the approach used was a normative assessment focused on quality. The indicators used were analyzed individually or grouped according to the components of pharmaceutical services. The assessment identified some good points, especially regarding the good availability of ARVs, and good guide patients in the use of these drugs, and also some problems such as low levels of compliance in relation to good dispensing practices criteria and storage and a high time for the distribution of medicines. The result was a degree of $50.3 \%$ compliance with the quality criteria, considered only regular in accordance with trial made. Proposals were suggested for actions and interventions, especially in relation to the improvement of structural conditions of pharmacies of health facilities in the city, and increased training of professionals involved in the services.
\end{abstract}

Uniterms: Pharmaceutical assistance/evaluation. Pharmaceutical assistance/Brazil. Brazilian public health system/assistance/HIV/AIDS.

\section{INTRODUCTION}

Brazilian Law No. 9313, enacted on November 13, 1996, grants all individuals with HIV infection the right to free receipts for all Antiretroviral Medications (ARV) needed (Brasil, 1996). The results from the implementation of this law made the Brazilian's AIDS patients' assistance program a world reference. Among its achievements we should point that, between 1997 and 2003, there was a $40-70 \%$ mortality reduction, a reduction in morbidity of over $60 \%$, and a ten-fold increase in survival after an AIDS diagnosis (Lago, Costa, 2010).

From a political point-of-view, the approval of this law was a major achievement for the social movements, although, from its start both the large investment in a disease with a low number of patients - at the expense of other more frequent or urgent ones - as the lack of infrastructure to manage drug distribution and dispensation, with the risk of no patient compliance, were questioned. (Lago, Costa, 2010). This challenge

\footnotetext{
*Correspondence: S. R. Castilho. Departamento de Farmácia e Administração Farmacêutica. Universidade Federal Fluminense. Rua Marquês do Paraná, 282, 24030-211, Niterói, RJ, Brasil. E-mail: selmarc@id.uff.br
}

increased at the end of 2013, with the recommendation of the early use of ARV for all people living with HIV/ AIDS (PLWHA), regardless of their CD4 count, which resulted in an increase in the use of these medications in the country (Brasil, 2013).

Despite the obvious health and social benefits of this policy, sustainability has always been threatened by it, due its high cost of implementation and execution. Several factors contribute to higher spending, such as the growing number of patients and demands for newer drugs (in general caused by the emergence of viral resistance) that are protected by patents and are usually imported (Lago, Costa, 2010).

Various strategies have been employed by the Brazilian Department of Health to reduce these costs, such as the centralised acquisition of ARVs, the encouragement of domestic production, and compulsory licensing and price negotiations with producers. (Loyola, 2008; Lago, Costa, 2010).

In this scenario of rising costs, ensuring the access to antiretroviral drugs, the pharmaceutical services for HIV/ AIDS had to be strengthened (Brasil, 2010). Even today, the efficient management of pharmaceutical services in all its aspects and components is vital to the success of the 
Brazilian HIV/AIDS program, allowing greater control over spending on ARVs and seeking effectiveness in the use of these products, especially through the pursuit of their rational use.

In this paper, it is assumed that access to medicine is "the relationship between the need for drugs and their supply, in which this need is met at the time and place required by the patient (consumer), with quality assurance and sufficient information for proper use" (Oliveira et al., 2002). Therefore, access is the availability plus quality and information.

In the Brazilian program to assist patients with HIV/AIDS, the stages of selection, scheduling and procurement of drugs, management, financing, and monitoring of the production of drugs are the sole responsibility of the Department of Health. In the case of storage and distribution the responsibility is shared between the Department of Health, Brazilian states and cities, leaving the steps of prescription and dispensing under the responsibility of the so-called Medication Dispensing Units (UDMs), which can be federal, state or municipal institutions, but under the coordination of City Administrations. Human resources management is the responsibility of all the domains involved, according to the activity performed (Brasil, 2010).

Local quality problems can, however, compromise the national programme. According to Portela and Lotrowka (2006), one should reflect on the quality of the care in a specific-focus programme, but not without strengthening the Brazilian health system as whole, as regional problems could affect the standards intended for the services.

In this program, not only the problems with drug supplying, but also in the process of storing, transporting and dispensing them, which increase the possibility of therapeutic failures and poor adherence by patients, can compromise the entire process and waste the resources invested by the program.

In order to detect possible management problems in pharmaceutical services focused on AIDS, and consequently subsidize interventions to improve and solve critical issues, this paper carried out a descriptive study of the pharmaceutical services for HIV/AIDS patients in the city of Niterói.

Two questions guided the work: (i) are the structure and conditions of the existing work processes adequate to ensure the quality of pharmaceutical services for people living with HIV/AIDS (PHVA) care in the city, and (ii) are the structure and work processes adequate to ensure access to antiretroviral drugs for opportunistic infections and PHVA care in the city?

\section{METHODS}

\section{Delimitation of the study/-assessment approach}

A descriptive cross-sectional study of the pharmaceutical services for HIV/AIDS patients was done in Niterói. The approach used was a normative assessment focused on quality, involving the analysis of structure, process and outcomes, as the valuation model proposed by Donabedian (1982). A logical and theoretical model was constructed for the development of multiple quality indicators. To that end, we conducted a literature review and applied experts' (stakeholders) opinions.

\section{Local study / analysis units}

The city of Niterói is located in the state of Rio de Janeiro, Brazil. A total 3,212 AIDS cases were reported from 1983 to 2013 in Niterói, with 199 new cases in 2012 and 169 in 2013 (Brasil, 2013b). All patients are seen at eight public health units, where all the health care is available for HIV/AIDS patients, including the dispensing of ARVs. In October 2013 a total 2,587 patients, including adults, children and pregnant women received ARVs for treatment and 24 for prophylaxis or occupational accidents (Brasil, 2013a). Those medications were dispensed in eight Medicine Dispensing Units (UDM) of the city.

Six UDMs coded 1-6 were evaluated in this work. One UDM was excluded from the survey as it did not authorize data collection in time. The other UDM was the pilot for the validation of data collection instruments, also being excluded from the analysis.

\section{Construction of the assessment}

The first step was the identification of pharmaceutical services in HIV/AIDS stakeholders, who were invited to participate in meetings aimed at defining the focus of the assessment. The next step was a logical model design to describe all the elements of the Pharmaceutical Services in HIV/AIDS in Niterói, showing their operation and the relationships and links between their components. The construction of this model was based on two pre-existing logical models, one proposed for a similar study (Oliveira et al., 2002) reality, and another proposed for the Brazilian public program named Basic Pharmacy (Cosendey, Hartz, Bermudez, 2003).

The logical model indicators were divided into four groups according to some components of pharmaceutical services (distribution, storage, and dispensing) under 
the responsibility of a city, and one more component, called qualifying, added by the authors. Most of the indicators (17) were selected directly or adapted from the literature. Others (3) have been developed by the authors in conjunction with the stakeholders.

The Steakholders were pharmacists working in pharmaceutical care in HIV/AIDS in the municipality, both at UDM and in Pharmacy Coordination. The five experts who participated had all at least 10 years in the profession, and not less than five years of activity in the STD/AIDS program. Initially meetings were conducted with these professionals to define the assessment focuses on the perspective of management, as well as defining the logical model (adaptation of Oliveira models, 2002 and Cosendey, 2003). These experts were also asked to assign weights 1-3 (3 being more relevant) to each proposed indicator. The average value of the weights was considered in the Relevance matrix.

\section{Data collection}

Data was collected through structured interviews with all Pharmacists responsible for the UDM. In addition, direct observation of specific points with the aid of assessment instruments was performed. Some documents, such as prescriptions, maps and reports from the logistic control program of the Department of Health (SICLOM), were also analyzed. Information on the medicine dispensing process was obtained by questionnaires applied to the users. The data was acquired mostly in a prospective way. However, some indicators were calculated based on retrospective data, especially those related to medical prescriptions and distribution data.

To collect data on medicines availability indicators, four visits were made in the period of two months, with intervals of approximately 15 days between them. The end result was defined by the average of the four observations. Thus, we sought to avoid the limitation pointed out by Oliveira et al. (2002), in which the absence of a drug at a single moment could be a consequence of prior service to all users of that particular drug.

To calculate the sample of users to be interviewed an absolute maximum error of $5 \%$ and a confidence level of $95 \%$ were considered. Based on the literature, we defined a minimum $15 \%$ orientation percentage in relation to the $\mathrm{C} 4$ indicator, and $85 \%$ for the $\mathrm{C} 5$ indicator (Luiza et al., 2006). The maximum expected number of users was set at 1,806 patients, the largest number of users served in October 2012, including the pilot unit. Thus, the sample of 154 patients, plus 8 in the pilot, was set.
The number of users to be interviewed in each UDM was obtained proportionally, considering the total number of expected users $(1,806)$ and the total number of patients seen per unit in the same month (October 2012). The selection and management of patients within each UDM were done for convenience, using the number of interview days needed to achieve the number of patients established in each UDM.

\section{Data analysis}

The data was tabulated using Microsoft Excel spreadsheets, Office 2007 and the Epiinfo Windows 3.5.2 program. At first, the indicators were calculated for each UDM. The calculation of the overall score for each indicator was obtained by the arithmetic mean of the results obtained by each individual UDM. However, for the $\mathrm{C} 4$ and $\mathrm{C} 5$ indicators, the final result for the city was based on the results of all patients interviewed, depending on the numerical range of interviews in each unit.

For indicators extracted from the literature, the same standards proposed by the original work were adopted. For those indicators suggested or adapted by the author, the parameter was obtained by a consensus amongst five (5) experts, all pharmacists, with a minimum 10 years in the profession, and no less than 5 years' activity in the sexuality transmited diseases - AIDS 'program.

These experts were also asked to assign weights 1-3 (3 being more relevant) to each proposed indicator. The average value of the weights was considered in the Relevance matrix. A score was then obtained for each indicator, as well as a general result of the evaluation. A Matrix analysis was obtained for each UDM and for the city as a whole.

The final score, which determined the degree for pharmaceutical services in HIV/AIDS quality, both for each UDM as for the county, was obtained by dividing the sum of the scores of each indicator by the maximum possible score for each indicator x 100 .

We sought to further evaluate the quality of pharmaceutical services components. Thus, we considered the four components which form the logical model, and found the degree of quality of each separately, according to the specific indicators in each component, to identify if there were any differences in quality between them, and if any of them had major or minor weaknesses or so-called 'critical nodes'.

This work was submitted to the Ethics Committee in Research of the School of Medicine, Universidade Federal Fluminense, Niterói, Brazil, having obtained an assent number 277020 on 20/05/2013. 


\section{RESULTS AND DISCUSSION}

\section{Logical model}

The logic model (Figure 1) used, incorporated to the models proposed by Oliveira et al. (2002) and Cosendey, Hartz and Bermudez (2003), the changes observed in the HIV/AIDS program, including the SICLOM implementation, as well as the so-called qualification component, suggested by Cosendey, Hartz and Bermudez (2003).
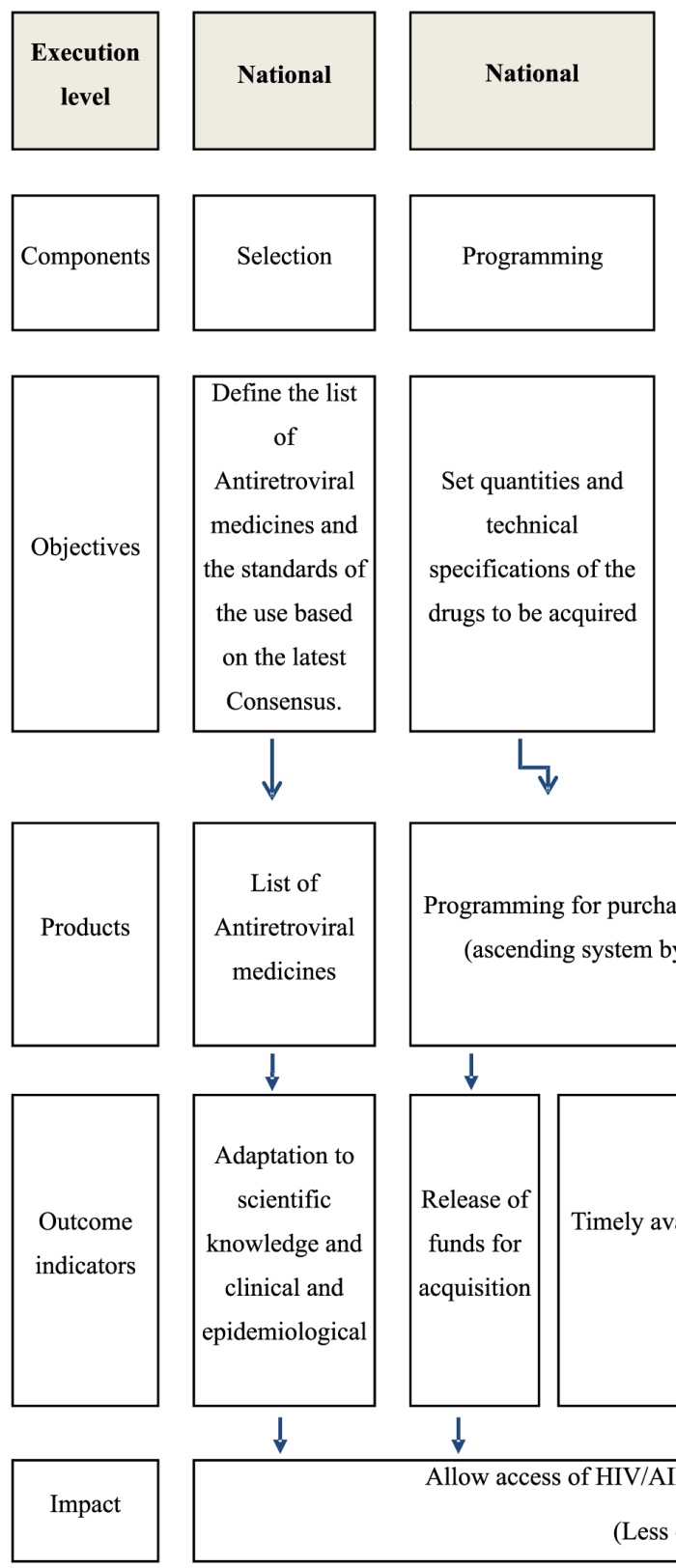

Programming for purchase of medicines (ascending system by SICLOM)
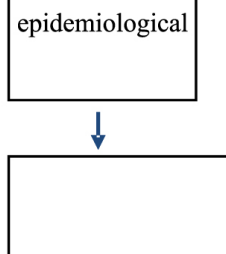
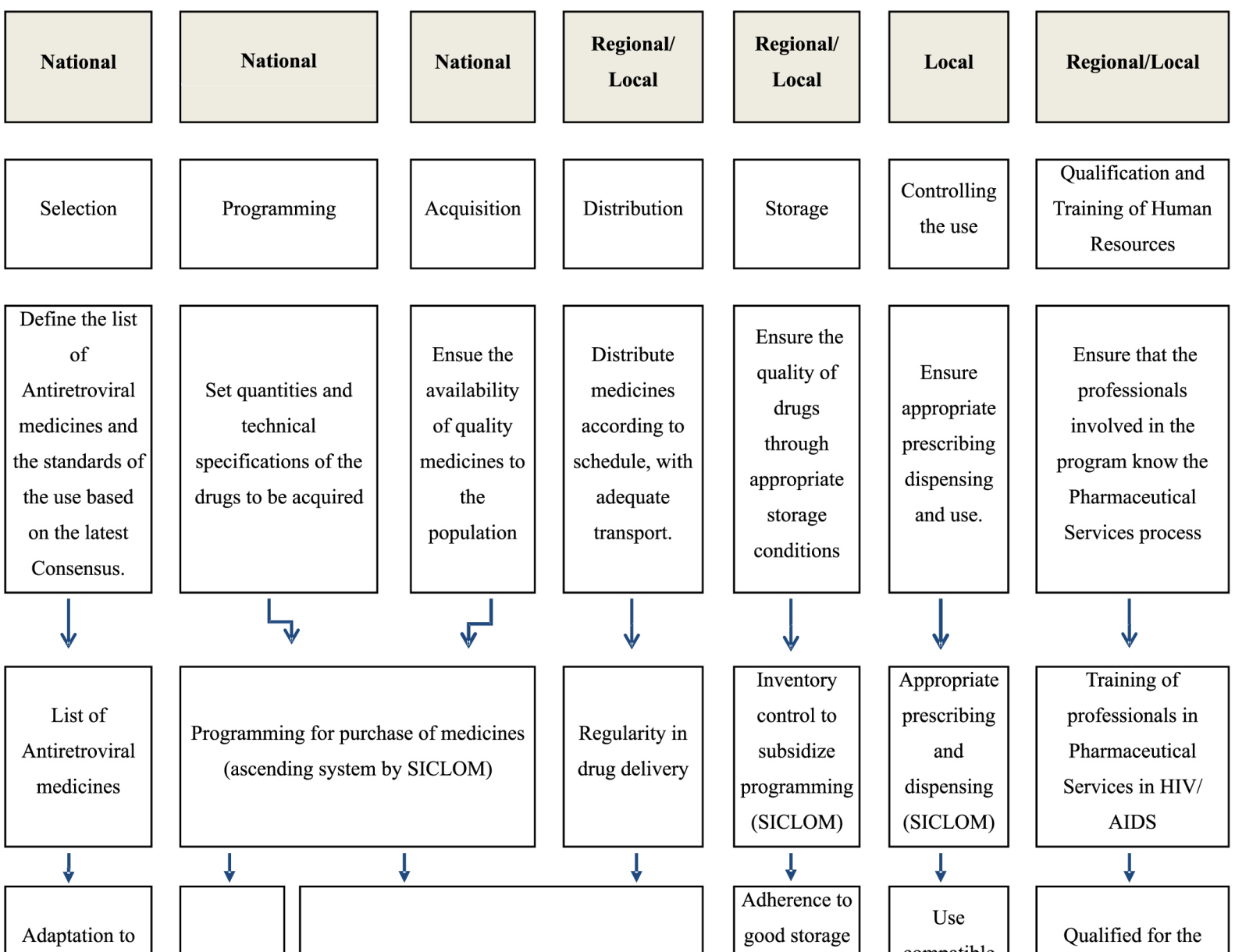

practices,

effectiveness

of inventory

control

(SICLOM)
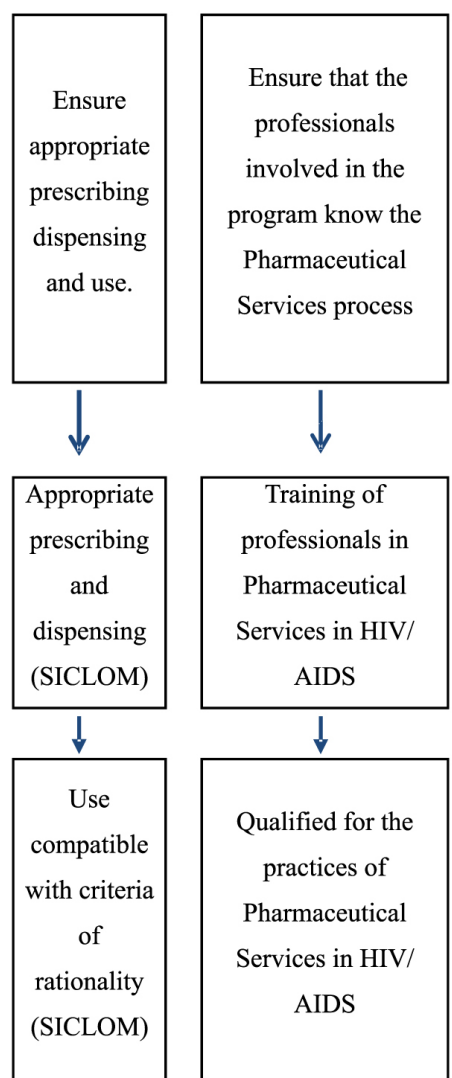

Qualified for the practices of

Pharmaceutical

Services in HIV/

AIDS
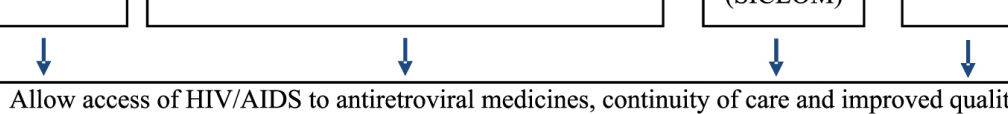

(Less opportunistic infections, fewer interactions and less deaths).

FIGURE 1 - Logic Model suggested for Pharmaceutical Services in HIV/AIDS in city of Niterói. (Adapted from Oliveira et al., 2002 and Cosendey, Hartz, Bermudez, 2003) 
TABLE I - List of indicators used and results obtained (average results for UDM)

\begin{tabular}{|c|c|c|c|c|c|}
\hline \multicolumn{6}{|c|}{ COMPONENT: DISTRIBUITION } \\
\hline Code & Indicator / Name & Calculation & Standard & Source & Average Result \\
\hline A1 & $\begin{array}{l}\text { Percentage of use of the } \\
\text { software SICLOM }\end{array}$ & $\begin{array}{c}\text { Use or not of SICLOM } \\
\text { software }\end{array}$ & $100 \%$ & Authors & $83,0 \%$ \\
\hline A2 & $\begin{array}{l}\text { Percentage of criteria } \\
\text { for Good Practices in } \\
\text { Transportation (GPT) }\end{array}$ & $\begin{array}{c}\text { Number of items with GPT / } \\
\text { number items (\%) }\end{array}$ & $100 \%$ & Authors & $25,0 \%$ \\
\hline A3 & $\begin{array}{c}\text { Percentage of items in } \\
\text { stock availability of ARV } \\
\text { medications }\end{array}$ & $\begin{array}{c}\text { Number in stock medicines } \\
\text { / medicines programmed } \\
\text { number }(\%) \\
\end{array}$ & Above $95 \%$ & $\begin{array}{c}\text { Oliveira et al., } 2002 \\
\text { Brasil, } 2008\end{array}$ & $96,7 \%$ \\
\hline A4 & $\begin{array}{l}\text { Percentage of items in stock } \\
\text { availability of drugs for } \\
\text { Opportunistic Infections }\end{array}$ & $\begin{array}{l}\text { Number in stock medicines } \\
\text { / medicines programmed } \\
\text { number }(\%) \\
\end{array}$ & Above $75 \%$ & $\begin{array}{c}\text { Oliveira et al., } 2002 \\
\text { Brasil, } 2008\end{array}$ & $73,8 \%$ \\
\hline A5 & Frequency distribution & $\begin{array}{c}\text { Time (in days) between the } \\
\text { request and the delivery of } \\
\text { drugs. }\end{array}$ & $\begin{array}{l}\text { Maximum of } 15 \\
\text { days }\end{array}$ & $\begin{array}{l}\text { Marin et al., } 2003 \\
\text { Luiza et al., } 2006\end{array}$ & 25,2 days \\
\hline A6 & $\begin{array}{l}\text { Availability of time for } \\
\text { introducing new treatments or } \\
\text { switching medications. }\end{array}$ & $\begin{array}{l}\text { Time between the medical } \\
\text { request and receipt by the } \\
\text { patient }\end{array}$ & Same day & $\begin{array}{l}\text { Adapted of Brasil, } \\
2008\end{array}$ & Same day \\
\hline A7 & $\begin{array}{l}\text { Availability of time for } \\
\text { exchange of drugs in special } \\
\text { situations (failure or exchange } \\
\text { for prescription drugs not } \\
\text { routinely) }\end{array}$ & $\begin{array}{l}\text { Time between the medical } \\
\text { request and receipt by the } \\
\text { patient }\end{array}$ & Within 7 days & Authors & 10,6 days \\
\hline \multicolumn{6}{|c|}{ COMPONENT: STORAGE } \\
\hline B1 & $\begin{array}{c}\text { Percentage of criteria for } \\
\text { Good Practice in Storage } \\
\text { (GPS) }\end{array}$ & $\begin{array}{c}\text { Number of items with GPS / } \\
\text { number items }(\%)\end{array}$ & $100 \%$ & $\begin{array}{l}\text { Adaptaded of } \\
\text { Oliveira } \text { et al., } 2002 \\
\text { and Marin } \text { et al., } \\
2003\end{array}$ & $73,7 \%$ \\
\hline B2 & Percentage of expired drugs & $\begin{array}{l}\text { Number of active ingredients } \\
\text { with expiration date overdue / } \\
\text { Total active ingredients }\end{array}$ & $0 \%$ & Oliveira et al., 2002 & $0 \%$ \\
\hline B3 & $\begin{array}{l}\text { Average percentage change in } \\
\text { inventory }\end{array}$ & $\begin{array}{l}\text { Calculate the difference } \\
\text { between the physical and the } \\
\text { record, the physical divide and } \\
\text { multiply by } 100 .\end{array}$ & $\begin{array}{r}\text { Maximum of } 5 \% \\
\text { (to more or less) }\end{array}$ & Oliveira et al., 2002 & $14,8 \%$ \\
\hline B4 & $\begin{array}{l}\text { Average percentage of the } \\
\text { stock record that does not } \\
\text { match the physical count for } \\
\text { ARV drugs in stock }\end{array}$ & $\begin{array}{c}\text { Number of items ranging } \\
\text { outside the range between } \\
95-105 \% \text { in relation to the } \\
\text { inventory divided by the total } \\
\text { number of items. }\end{array}$ & $\begin{array}{l}\text { Maximum of } 5 \% \\
\text { of the items. }\end{array}$ & $\begin{array}{c}\text { Adaptaded of } \\
\text { Oliveira } \text { et al., } 2002\end{array}$ & $33,7 \%$ \\
\hline \multicolumn{6}{|c|}{ COMPONENT: DISPENSING } \\
\hline $\mathrm{C} 1$ & $\begin{array}{l}\text { Percentage of criteria for } \\
\text { Good Practice of Dispensing } \\
\text { (GPD) }\end{array}$ & $\begin{array}{c}\text { Number of items with GPD / } \\
\text { number items (\%) }\end{array}$ & $100 \%$ & $\begin{array}{c}\text { Adaptaded of } \\
\text { Oliveira et al., } 2002\end{array}$ & $51,2 \%$ \\
\hline $\mathrm{C} 2$ & $\begin{array}{c}\text { Utilization percentage of } \\
\text { software OPERATIONAL } \\
\text { SICLOM in procedures of } \\
\text { dispensing }\end{array}$ & $\begin{array}{l}\text { Number of UDM using the } \\
\text { SICLOM in procedures } \\
\text { dispensing / Total number of } \\
\text { UDM }\end{array}$ & $100 \%$ & $\begin{array}{c}\text { Adaptaded of Sakita, } \\
2012\end{array}$ & $33,3 \%$ \\
\hline
\end{tabular}


TABLE I - List of indicators used and results obtained (average results for UDM) (cont.)

\begin{tabular}{|c|c|c|c|c|c|}
\hline \multicolumn{6}{|c|}{ COMPONENT: DISPENSING } \\
\hline Code & Indicator / Name & Calculation & Standard & Source & Average Result \\
\hline $\mathrm{C} 3$ & $\begin{array}{l}\text { Percentage of prescriptions } \\
\text { in accordance with the } \\
\text { Brazilian Current consensus } \\
\text { for treatment of patients with } \\
\text { HIV/ AIDS }\end{array}$ & $\begin{array}{l}\text { Prescriptions acceptable } \\
\text { number / number of } \\
\text { prescriptions analyzed }\end{array}$ & $100 \%$ & Oliveira et al., 2002 & $100 \%$ \\
\hline $\mathrm{C} 4$ & $\begin{array}{l}\text { Percentage of patients with } \\
\text { guidance in the dispensation }\end{array}$ & $\begin{array}{c}\text { Number of targeted patients / } \\
\text { Number of patients }\end{array}$ & Above $40 \%$ & Luiza et al., 2006 & $25,3 \%$ \\
\hline $\mathrm{C} 5$ & $\begin{array}{l}\text { Percentage of patients with } \\
\text { correct use of medicines }\end{array}$ & $\begin{array}{l}\text { Number of patients with } \\
\text { correct use / number of } \\
\text { patients }\end{array}$ & Above $75 \%$ & Luiza et al., 2006 & $94,8 \%$ \\
\hline \multicolumn{6}{|c|}{ COMPONENT: QUALIFICATION } \\
\hline D1 & $\begin{array}{l}\text { Percentage of Pharmacists } \\
\text { with training in HIV/ AIDS }\end{array}$ & $\begin{array}{c}\text { Number of trained } \\
\text { pharmaceutical / } \\
\text { pharmaceutical number }(\%)\end{array}$ & $100 \%$ & Luiza et al., 2006 & $100 \%$ \\
\hline $\mathrm{D} 2$ & $\begin{array}{l}\text { Percentage of Dispensers with } \\
\text { training in HIV/ AIDS }\end{array}$ & $\begin{array}{c}\text { Number of trained dispensers / } \\
\text { dispensers number }(\%)\end{array}$ & $100 \%$ & Luiza et al., 2006 & $46,7 \%$ \\
\hline D3 & $\begin{array}{c}\text { Percentage of UDM that have } \\
\text { valid sources of information } \\
\text { about medicines }\end{array}$ & $\begin{array}{c}\text { Use the UDM or not valid } \\
\text { sources of information about } \\
\text { medicines }\end{array}$ & $100 \%$ & Luiza et al., 2006 & $33,3 \%$ \\
\hline D4 & $\begin{array}{l}\text { Percentage of workload of the } \\
\text { pharmacist dedicated to the } \\
\text { program HIV/AIDS }\end{array}$ & $\begin{array}{l}\text { Number of hours available } \\
\text { of Pharmacist (s) Number of } \\
\text { hours care program for HIV } \\
\text { AIDS Unit (\%) }\end{array}$ & $100 \%$ & $\begin{array}{c}\text { Adaptaded of Brasil, } \\
2008\end{array}$ & $24,7 \%$ \\
\hline
\end{tabular}

TABLE II - Matrix for value judgment of quality of the pharmaceutical services in HIV/AIDS in Niterói, Brazil

\begin{tabular}{cc}
\hline Percentage Obtained & Degree Of Quality \\
\hline$\geq 80$ & Optimal \\
60 a 79,9 & Good \\
40,0 a 59,9 & Regular \\
$\leq 39,9$ & Bad \\
\hline
\end{tabular}

a different ciy (Rio de Janeiro) and at the beginning of the national program implementation.

The average score for the indicator of Good Transport Practice (GPT) was of only $25 \%$ (Standard Deviation $(\mathrm{SD})=0.14)$, suggesting serious problems regarding drug transport. The vehicles used were not adequate in any of the UDM, including the fact that they had no conditions for the transport of labile drugs.

The mean availability in stock for ARV drugs was $96.7 \%$ ( $\mathrm{SD}=1.03)$. Other studies obtained similar results (Oliveira et al., 2002; Melchior et al., 2006), while a study had an average availability of $88 \%$ for these drugs
(Luiza et al., 2006). We should point that those studies applied tracer medicines for availability check, whereas the present study evaluated the presence in the stock of all the medicines used by the UDM.

As regards the availability of drugs for opportunistic infections, the result $(73.8 \%)(\mathrm{SD}=8.3)$ was much lower than that for the ARV. It should be noted that four data collections were considered to assess the availability in each UDM. The value obtained approximates the mean availability found by Luiza et al. (2006), which was $63 \%$.

The average time for the delivery of ARV drugs to the UDM, considered from the first working day of the month (when it is possible to make a monthly request for drugs via the SICLOM software) was of 25.2 days $(\mathrm{SD}=0.25)$. One can consider this a very long-term delivery as, although the SICLOM software considers calculating a sufficient stock for two months, the request always involves the amount needed to complete the inventory required to meet that period. As there are variations in consumption in some months, the amount of a specific drug may be insufficient in this 25-day period, increasing the risk of shortages. 
All UDM, even the smallest ones, reported having ARV drugs for the immediate treatment of any new patient. These results are consistent with the patterns shown by the evaluation of the AIDS Program of the Brazilian Department of Health (Qualiaids), in 2010, that showed only $73.1 \%$ of the UDM surveyed had ARV drugs available for initial treatment. (Brasil, 2008a)

Regarding the availability of time for changing of drugs in special situations (treatment failure or unusual drugs), the general average seen (10.6 days) was above the one considered ideal by the experts who took part in this work. It is important to note that this indicator was suggested due to difficulties to provide medicines to patients in the case of therapeutic exchanges.

The average score for the indicator measuring the Good Storage Practices (GSP) was 73.7\% (SD=11.4), which shows that storage conditions varied greatly amongst the UDM. Some had good storage conditions, while others were quite poor in terms of physical structure, without even a proper and exclusive place for the service of Pharmacy, which shared it with other sectors of the work. Other studies also found similar results (Brasil, 2005; Luiza et al., 2006; De Bernardi, Bierbach, Thomé, 2006; Correia, Coelho, 2009). Oliveira et al. (2002), however, found lower values. During the period of data collection, no drug with an expired validity date was found in the UDM.

The variability pointers for stocks of ARV drugs found an average percentage change in the inventory of $14.8 \%(\mathrm{SD}=5.5)$ and the percentage in the number of items ranging above $5 \%$ in the respective inventory was, on average, $33.6 \%(\mathrm{SD}=13.3)$. This suggests the occurrence of errors, whether in inventory control, including the handling of the computerized system or, what is more serious, in the dispensing process. The origin of these differences was not the object of this work and their identification requires a higher level of detail.

The average score for the indicator of Good Practice Dispensing (GPD) was 51.2\% (SD = 19.1), which also shows a great variation in the result between UDM, but with a relatively low average value, indicating a need for programmatic interventions to improve medicine dispensing practices.

It should also be pointed that although all UDM declare that pharmacists supervise the dispensing process, only four reported some level of pharmaceutical care provided, and there is no kind of pharmaco-therapeutic monitoring. More worrying is the fact that the consensus guidelines of the Department of Health (Brasil, 2008; Brasil, 2013) are available for consultation at only two UDM and that only one had another source of information beyond the consensus itself to support patient care.
The non-participation of pharmacists in adherence groups and, in some UDM, the lack of control of absentees could also indicate a low insertion of the pharmacist in interdisciplinary health care team.

Only two UDM reported using SICLOM's dispensing processes at the exact moment the ARV drug is delivered to the patient. We should point that the national AIDS programme suggests that it should be used to support dispensing, especially because the system allows, besides verifying the adequacy of the date of withdrawal of the drug, to detect potential prescription errors (unauthorized associations, for example) at the exact time of dispensing of drugs.

All ARV prescriptions dispensed at the UDM in July 2013 were evaluated for their consistency with the Brazilian consensus in use at the date of data collection (Brasil, 2008). None of the prescriptions analyzed contained dosage problems or contraindicated associations. (Brasil, 2008; Brasil, 2013). However, it is important to emphasize that a deeper analysis of the therapeutic approach was not in the objectives of this work, and only absolute contraindications in ARV drug combinations were considered.

Of the 154 patients interviewed, 39 (25.3\%) reported being instructed, at some point, by the UDM pharmacy, and 146 patients $(94.8 \%)$ demonstrated a correct use of the medication. The average age of patients was 45.5 years $(\mathrm{SD}=17.5)$. There was no significant difference in response according to gender in any of the two questions, using the chi square Yates corrected, with one degree of freedom ( $\mathrm{p}=1.2688$ and 1.3395 respectively).

The results were similar to those obtained by Luiza et al., (2006), where on average only $15.9 \%$ of users considered they received some guidance about their medicines at the pharmacy. In this same study $84.0 \%$ of patients knew the basic usage of the prescription drugs. Other studies have found a value of $77.6 \%$ of users with basic knowledge about medicines (Brasil, 2005).

Despite the low percentage of patients that said they had been advised at the pharmacy at some time during their treatment, the majority $(94.8 \%)$ correctly described the use of the ARV drugs, at least in matters related to the identification of drug dosages and schedules. This fact can be explained by the typical characteristics of the HIV/ AIDS programme that encourage increased involvement of all the professionals involved in the issues related to adherence to treatment. A common response from patients was that there was no great need for information from the pharmacy as the doctor and other professionals had already oriented them.

All pharmacists in all the UDM were trained at some 
point in pharmaceutical services in the treatment of AIDS. An important issue is that, according to some reports (four out of six pharmacists interviewed), the frequency of training has declined in recent years.

An interesting point is that the skills that involve more basic issues, such as AIDS and adherence counselling, were done during the older training program, usually at the start of the program at the UDM. Perhaps this explains the fact that some of the pharmacists more recently engaged in the AIDS program (41.7\%) were not trained in those aspects.

In relation to the training of non-pharmacists that participate of the dispensing process, only an average $47,0 \%$ were trained $(\mathrm{SD}=37.6)$. It is important to note the fact that in some UDMs, although those people had been trained to use the SICLOM software, its use in routine work is low.

Only two UDM (33\%) reported they have their own valid sources of information on medicines. Beyond that, some pharmacists did not receive training in AIDS therapeutic issues. Both the lack of access to sources of information as well as the deficiency in training can compromise medication therapeutic management. It is worth mentioning that the two UDM that have information sources are the same that reported having a recent copy of the latest AIDS therapeutical consensus.

Regarding the number of hours available from the pharmacist, as most UDM work on non-exclusive outpatient pharmacies for HIV/AIDS patients, pharmacists were asked to estimate how many hours per week are dedicated to the AIDS/HIV program. This value was divided by the total number of hours in which AIDS patients are cared for at the UDM. The overall average score for this indicator was of only $24.7 \%(\mathrm{SD}=13.2)$, indicating the workload of pharmacists dedicated to the program.

\section{Results of the assessment of Pharmaceutical Services Components}

Table III show the overall result for each component of the pharmaceutical services.

It can be seen that only the component Distribution had a good result, basically because of the good percentage obtained by drug availability indicators. In contrast, the result for component Qualification had a poor result, which suggests the need for the further training of pharmacists and dispensers mainly. The other components were considered reasonable, which will also require an effort to improve, especially because they are the main activities of the pharmacists.
TABLE III - Overall result for the assessment for the Health Foundation of Niterói city (HFN) for pharmaceutical services components

\begin{tabular}{lc}
\hline Components & Percentage \\
\hline Distribuition & 61,4 \\
Storage & 45,5 \\
Dispensing & 53,3 \\
Qualification & 30,0 \\
\hline
\end{tabular}

\section{Overall result of the evaluation}

Table IV shows the overall result of the evaluation per UDM and the overall result for the city, with a $50.3 \%$ grade for the quality of pharmaceutical services, considered only regular according to the parameters presented in Table II. The result is lower than that obtained by Oliveira et al., (2002) who found $89 \%$ in programme implementation.

It is important to note that, in the 2002, the program was being implemented and SICLOM was not even being used yet. Besides that, Oliveira et al., (2002) published their study before or at the beginning of the implementation of the National Pharmaceutical Assistance policy. Nowadays, in one hand, SICLOM is a reality that facilitates some work processes, especially in dispensing drugs, but the complexity of pharmaceutical care processes in HIV/AIDS is higher. It is also important to emphasize that in the current reality, it was observed a good availability of drugs but the pharmacist's work processes have not reached satisfactory levels.

TABLE IV - Quality degree of the pharmaceutical services in HIV/AIDS in the Health Foundation of Niterói city (FMS) (value judgment)

\begin{tabular}{lcc}
\hline UDM & Value & Quality degree \\
\hline UDM2 & 56,4 & Regular \\
UDM3 & 61,8 & Good \\
UDM4 & 44,2 & Regular \\
UDM5 & 50,3 & Regular \\
UDM6 & 49,1 & Regular \\
UDM7 & 70,9 & Good \\
\hline FMS & 50,3 & Regular \\
\hline
\end{tabular}

\section{CONCLUSION}

The results obtained in this work allowed answering the evaluative questions, observing that the degree of 
quality of the pharmaceutical services for HIV/AIDS patients in Niterói, was on average $50 \%$. However, there was a heterogeneous scenario between the UDMs, with two of them showing a good quality degree.

Access to drugs was considered satisfactory in relation to ARV medication, and only reasonable in relation to drugs for opportunistic infections. But the concept of access includes the availability and quality of the information. Thus, one can consider that the access was only partial, as the availability of drugs was not followed by a good compliance and quality of pharmaceutical care services.

The assessment offered subsidies to detect strengths and weaknesses in the pharmaceutical services. Among the strengths, the availability of ARVs stands out, as well as the absence of expired medications and of prescriptions at odds with the HIV/AIDS treatment consensus, besides well-targeted patients in the use of ARV drugs. As weaknesses, the low levels of compliance against criteria of good pharmaceutical practices, both in transport, storage and dispensing medications are highlighted, as well as the low use of the SICLOM program in the process of dispensation.

It is necessary, therefore to see an urgent improvement of the pharmacies' infrastructural conditions at the nonexclusive units of the program, in which, mostly, both local storage of medicines, and the space for medicine dispensing are limited and precarious. These changes should also include improving transport conditions, with the use of suitable transport vehicles.

Another important issue is the need to change the delivery logistics of ARV drugs for the city of Niterói, (which are set by the Brazilian Department of Health in conjunction with the State Government of Rio de Janeiro). This is to reduce the excessive time between the ARV drugs being requested by the city through SICLOM and the effective delivery of the products.

As already proposed in previous studies (Oliveira et al., 2002) it is essential to increase the number and frequency of training programs for pharmacists and dispensers, including periodic training on the SICLOM's routine use, the AIDS disease in all of its aspects (diagnosis, epidemiology, treatment, etc.) and on pharmaceutical services in HIV/AIDS in particular.

Finally, it would be important to conduct studies to verify the possibility of reorganization of work processes related to dispensing activities, with most of the attention focused on the patient, such as pharmaceutical care deployment, or patient education/counselling activities that could improve the quality of therapeutic outcomes by increasing the adherence to treatment. These should include the possibility of physical and structural reforms in UDMs and a re-definition of the human resources needed to accomplish those goals.

The problems identified in this study are mostly not unique to the AIDS program, but reflect the lack of structural conditions of health facilities that affect program quality, including pharmaceutical services as a whole. Although the AIDS program has its own unique features which mainly reflect a greater availability of resources (medicines, equipment such as computers, etc.), the program cannot operate completely isolated from the context in which it functions.

\section{REFERENCES}

BRASIL. Presidência da República. Casa Civil. Subchefia para Assuntos Jurídicos. Lei N09.313 de 13 de Novembro de 1996. Dispõe sobre a Distribuição Gratuita de Medicamentos aos portadores do vírus HIV e Doentes de AIDS. Brasília, 1996. Disponível em: < http://www.planalto. gov.br/ccivil_03/leis/19313.htm>. Acesso em: 07 Nov. 2013.

BRASIL. Ministério da Saúde. Organização Pan-Americana da Saúde. Avaliação da Assistência Farmacêutica no Brasil. Brasília: Organização Pan-Americana da Saúde; Ministério da Saúde, 2005. 260p. (Série técnica medicamentos e outros insumos essenciais para a saúde).

BRASIL. Ministério da Saúde. Secretaria de Vigilância em Saúde. Programa Nacional de DST e AIDS. Recomendações para Terapia Anti-Retroviral em Adultos Infectados pelo HIV: 2008. 7. ed. Brasília: Ministério da Saúde, 2008. 244p.

BRASIL. Ministério da Saúde. Secretaria de Vigilância em Saúde. Departamento de DST, AIDS e Hepatites Virais. QUALIAIDS: avaliação e monitoramento da qualidade da assistência ambulatorial em AIDS no SUS. Brasília: Ministério da Saúde, 2008a. 100p.

BRASIL. Ministério da Saúde. Secretaria de Vigilância em Saúde. Departamento de DST, AIDS e Hepatites Virais. Protocolo de assistência farmacêutica em DST/HIV/AIDS. recomendações do Grupo de Trabalho de Assistência Farmacêutica. Brasília: Ministério da Saúde, 2010. 224p.

BRASIL. Ministério da Saúde. Secretaria de Vigilância em Saúde. Programa Nacional de DST e AIDS. Protocolo clínico e diretrizes terapêuticas para adultos vivendo com HIV/AIDS: 2013. Brasília: Ministério da Saúde, 2013. 75p. 
BRASIL. Ministério da Saúde. Secretaria de Vigilância em Saúde. Departamento de DST, AIDS e Hepatites Virais.

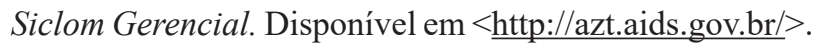
Acesso em: 04 Nov. 2013a.

BRASIL. Ministério da Saúde. Sistema de Informação deAgravos de Notificação SINAN. Disponível em: <http:// portalsinan.saude.gov.br/dados-epidemiologicos-sinan $>$. Acesso em: 12 Nov. 2013b.

CORREIA, A.R.F.; COELHO H.L.L. Avaliação da Assistência Farmacêutica em Fortaleza: estrutura, processo e resultados. Fortaleza: Universidade Federal do Ceará, 2009. 132p. (Cadernos do GPUIM. Série A: Assistência Farmacêutica).

COSENDEY, M.A.E.; HART, Z.M.A.; BERMUDEZ, J.A.Z. Validation of a tool for assessing the quality of pharmaceutical services. Cad. Saúde Pública., v.19, n.2, p. 395-406, 2003.

DONABEDIAN, A. The quality of medical care: a concept in search of a definition. J. Farm. Pract., v.9, n.2, p.975-92, 1982.

DE BERNARDI, C.L.B.; BIERBACH, E.W.; THOMÉ, H.I. Avaliação da Assistência Farmacêutica Básica nos municípios de abrangência da $17^{\mathrm{a}}$ Coordenadoria Regional de Saúde do Rio Grande do Sul. Saúde Soc., v.15, n1, p.7383, 2006.

LAGO, R.F.; COSTA, N.R. Dilemas da política de distribuição de medicamentos Antiretrovirais no Brasil. Ciênc. Saúde Coletiva, v.15, Supl.3, p.3529-3540, 2010.

LOYOLA, M.A. Medicamentos e saúde pública em tempos de AIDS: metamorfose de uma política dependente. Ciênc. Saúde Coletiva, v.13, Supl., p.763-778, 2008.
LUÍZA, V.L.; ESHER, A.; EMMERICKI, C.M.; SANTOS, E.M.; AVELAR, F.G.; OLIVEIRA, M.A.; CAMPOS, M.R.; AZEREDO, T.A. Avaliação Nacional da Dispensação de Medicamentos para as PVHA. Relatório final de Pesquisa: Fundação Oswaldo Cruz (Fiocruz), Escola Nacional de Saúde Pública (ENSP), Núcleo de Assistência Farmacêutica. Rio de Janeiro, 2006.

MARIN, N.; LUZIA, V.L.; OSÓRIO DE CASTRO, C. G. S.; MACHADO DOS SANTOS, S. Assistência Farmacêutica para gerentes municipais. Rio de Janeiro: OPAS/OMS, 2003. 337p.

MELCHIOR, R.; NEMES, M.I.B.; BASSO, C.R.; CASTANHEIRA, E.R.L.; BRITO E ALVES, M.T.S.; BUCHALLA, C.M.; DONINI, A.A. Avaliação da estrutura organizacional da assistência ambulatorial em HIV/AIDS no Brasil. Rev. Saúde Pública v.40, n.1, p.143-51, 2006.

OLIVEIRA, M.A.; ESHER, A.F.S.C.; SANTOS, E.M.; COSENDEY, M.A.E.; LUÍZA, V.L.; BERMUDEZ, J.A.Z. Avaliação da assistência farmacêutica às pessoas vivendo com HIV/AIDS no município do Rio de Janeiro. Cad. Saúde Pública, v.18, n.5, p.1429-1439, 2002.

PORTELA, M.C.; LOTROWSKA, M. Assistência aos pacientes com HIV/AIDS no Brasil. Rev. Saúde Pública, v.40, Supl., p.70-79, 2006.

SAKITA, K.M. Avaliação da implantação do Sistema de Controle Logístico de Medicamentos/AIDS: o caso do Distrito Federal. 2012. 87f. Dissertação (Modalidade Profissional em Saúde Pública) - Escola Nacional de Saúde Pública, Fundação Oswaldo Cruz, Rio de Janeiro, 2012.

Received for publication on $17^{\text {th }}$ June 2016 Accepted for publication on $08^{\text {th }}$ November 2016 